\title{
Reduced expression of transforming growth factor-beta receptor type III in high stage neuroblastomas
}

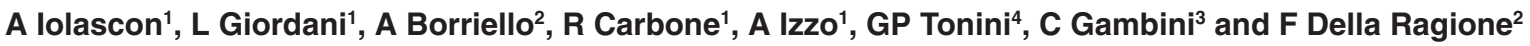 \\ 'Department of 'Biomedicina dell'Età Evolutiva', University of Bari, Piazza G. Cesac̀e 11, 70124 Bari, Italy; ${ }^{2}$ nnstitute of Biochemistry of Macromolecules, Second \\ University of Naples, Italy; ${ }^{3}$ Divison of Pathology, Giannina Gaslini Children's Hospital, Genova, Italy; ${ }^{4}$ Advanced Biotechnology Center, Genova, Italy
}

\begin{abstract}
Summary Transforming growth factor beta (TGF- $\beta$ ) is a powerful inhibitor of cell proliferation and a potent inducer of differentiation. Resistance to TGF- $\beta$ action is a characteristic of many malignancies and has been attributed to alterations of TGF- $\beta$ receptors as well as disturbance of downstream transduction pathways. To analyse the TGF- $\beta$ response in neuroblastoma, the expression of TGF- $\beta 1$ and TGF- $\beta$ type I, II and III receptor genes was investigated in 61 cancer samples by means of reverse transcription polymerase chain reaction. The specimens analysed belong to different stages, namely nine samples of stage 1, ten of stage 2, nine of stage 3 and 28 of stage 4 . Moreover, five samples were of stage $4 \mathrm{~S}$, which represents a tumour form undergoing spontaneous regression. The results obtained show that TGF- $\beta 1$ and TGF- $\beta$ type I and II receptor genes appear to be almost equally expressed in neuroblastomas of all stages. Conversely, TGF- $\beta$ type III receptor gene expression, which is required for an efficacious TGF- $\beta$ binding and function, is strongly reduced exclusively in neuroblastomas of stages 3 and 4 . These findings were directly confirmed by immunohistochemical analyses of ten neuroblastoma specimens. Our results suggest the occurrence of an altered TGF- $\beta$ response in advanced neuroblastomas which might be an important mechanism for escaping growth control and for developing invasiveness. Moreover, our findings allow the proposal of a novel mechanism, namely down-regulation of TGF- $\beta$ type III receptor gene expression, to avoid TGF- $\beta$ inhibitory activity. @ 2000 Cancer Research Campaign
\end{abstract}

Keywords: TGF- $\beta 1$; TGF- $\beta$ RI; TGF- $\beta$ RII; TGF- $\beta$ RIII; neuroblastoma

Neuroblastomas derive from the arrested differentiation of neural crest sympathoadrenal progenitor cells. Clinical evidences indicate that this differentiation block is reversible, since a large percentage of localized early-stage cancers and the majority of the congenital disseminated forms of neuroblastoma might undergo spontaneous regression (Siegel and Sato, 1986). On the other hand, high-stage metastatic neuroblastomas (stages 3 and 4) are generally less differentiated and more primitive than their localized stages. However, high-stage neuroblastomas may differentiate, as shown by the ability of their derived cell lines to acquire neuronal cell morphology and markers. Unfortunately, patients with advanced stage neuroblastoma have poor outcome and scarce long-term survival, even after aggressive therapy (Pinkerton, 1993).

On the basis of these findings, it appears important to investigate, in neuroblastoma, the molecular mechanisms involved in the interplay between proliferation and differentiation. In particular, studies on genes which have been demonstrated to play a key function in differentiation are of pivotal relevance.

A pivotal pathway, involved in the control of proliferation/ differentiation, requires the activation of transforming growth factor beta (TGF- $\beta$ ) receptors and the cascade of events which finally results in growth impairment and differentiation. TGF- $\beta$ exerts its effect by interacting mainly with three membrane proteins named type I (RI), type II (RII) and type III (RIII) receptors.

Received 10 May 1999

Revised 18 October 1999

Accepted 2 November 1999

Correspondence to: A lolascon
TGF- $\beta$ RI and TGF- $\beta$ RII form a heterodimeric or heterotetrameric complex (with one to one stoichiometry) necessary for TGF- $\beta$ signal transduction (Heldin et al, 1997), while TGF- $\beta$ RIII (also called $\beta$-glycan) is required to allow (by increasing the affinity) the binding of TGF- $\beta$ RII to the various TGF- $\beta$ isoforms.

A number of studies have investigated the occurrence in human cancers of structural and functional alterations of TGF- $\beta$ RI and TGF- $\beta$ RII genes. Mutations of TGF- $\beta$ RII occur in human malignancies, including retinoblastoma and colon cancers and in cell lines derived from carcinomas of the uterine cervix (Coffey et al, 1987; Kimchi et al, 1988; Lu et al, 1995; Markowitz et al, 1995). Moreover, several investigations demonstrated a lower expression of TGF- $\beta$ RI and TGF- $\beta$ RII genes in human malignancies (Kadin et al, 1994; Matoba et al, 1998; Royuela et al, 1998; Hougaard et al, 1999). These results have been confirmed by the observation that the forced expression of TGF- $\beta$ RI and TGF- $\beta$ RII genes remarkably reduces malignancy in the recipient cancer cell lines (Sun et al, 1994; Wang et al, 1996).

On the other hand, to the best of our knowledge, only one study on TGF-ßRIII transcript in human cancers has been carried out. This very recent investigation demonstrated an impairment of TGF-ßRIII expression in ovarian carcinomas (Bristow et al, 1999). In this scenario it is important to note that recently it has also been shown that TGF- $\beta$ RIII overexpression restores an apparent unresponsiveness of breast cancer cells to the inhibitory action of TGF- $\beta 1$ (Chen et al, 1997). Thus, down-regulation of TGF- $\beta$ RIII might be an additional important mechanism of malignant cells for escaping TGF- $\beta$-induced growth inhibition and induction of differentiation.

Although TGF- $\beta 1$ and TGF- $\beta$ receptor genes are involved in the control of cell differentiation and neuroblastoma development is 
linked to differentiation arrest, no studies have been carried out so far to analyse the expression of these four genes in human neuroblastomas. This investigation is peculiarly important in view of the observation that neuronal tissue is responsive to TGF- $\beta$ control. Moreover, very few investigations have been performed on TGFBRIII expression in human tumours even though, as discussed above, this gene might also be considered as a potential cancer suppressor gene.

In this report, we described the first investigation on TGF- $\beta$ and TGF- $\beta$ receptor (type I, II and III) gene expression in a large series (61 specimens) of human neuroblastoma. This study was carried out in order to evaluate the role of these genes in the development and evolution of such a frequent paediatric tumour. The results obtained were also compared with two other neuroblastoma important genetic features, namely $\mathrm{N}-m y c$ gene amplification and $1 \mathrm{p}$ chromosome status.

\section{MATERIALS AND METHODS}

\section{Tumour samples}

Sixty-one primary tumour samples, belonging to the Italian Tissue Bank, were selected to represent the distribution of stages found in neuroblastoma. Patients were staged according to the revised INSS staging system (Brodeur et al, 1993). The resected tumours were frozen immediately in liquid nitrogen and stored at $-80^{\circ} \mathrm{C}$ until analysis. Diagnosis was established by histological examination of tumour tissue obtained at surgery. In order to ensure that tumour samples used for molecular analyses contained a sufficient proportion of malignant cells, several cytological and histological evaluations of each sample were performed. Thus, only samples which were clearly demonstrated to contain more than $95 \%$ tumour cells were used in the present study. This allowed us to rule out the possibility that the obtained results were due to normal cells present in the analysed specimens.

\section{RT-PCR}

Reverse transcription polymerase chain reaction (RT-PCR) analysis was performed using the StrataScript RT-PCR Kit (Stratagene, La Jolla, CA, USA). Briefly, $2.5 \mu \mathrm{g}$ of total RNA, prepared as reported (Iolascon et al, 1998b), were reverse-transcribed by StrataScript RNAase H- reverse transcriptase (25 U) using oligo(dT) primer $(150 \mathrm{ng})$ in a final volume of $25 \mu \mathrm{l}$. cDNA samples were diluted tenfold in a PCR reaction assay to a volume of $50 \mu \mathrm{l}$ containing, in addition to the DNA template, $30 \mathrm{~mm}$ Tris- $\mathrm{HCl}$ ( $\mathrm{pH}$ 9.0), $50 \mathrm{~mm}$ potassium chloride, $1.5 \mathrm{~mm}$ magnesium chloride, $200 \mu \mathrm{g}$ of each primer, $0.2 \mathrm{mM}$ of each nucleotide and 1 unit of Taq DNA polymerase. Temperature conditions and primers for glyceraldehyde 3-phosphate dehydrogenase (GAPDH) were previously reported (Iolascon et al, 1998b).

Primers used for TGF- $\beta 1$ were as follows: $5^{\prime}$-TGTCCCCTATCCCCTGACTCCC-3', and 5'-CCCAGCCTGGAAGGCCTCCATC-3' (amplified fragment of $221 \mathrm{bp}$ ). Temperature conditions for TGF- $\beta 1$ were: hot start at $95^{\circ} \mathrm{C}$ for $5 \mathrm{~min}, 30$ cycles composed of steps at $95^{\circ} \mathrm{C}$ for $1 \mathrm{~min}, 65^{\circ} \mathrm{C}$ for $1 \mathrm{~min}, 72^{\circ} \mathrm{C}$ for $1 \mathrm{~min}$ and a final elongation step at $72^{\circ} \mathrm{C}$ for $7 \mathrm{~min}$.

Primers used for TGF- $\beta$ RI were as follows: $5^{\prime}$-ATTCCTCGAGATAGGCCGTT-3', and 5'-AGGGCGATCTAATGAAGGGT-3' (amplified fragment of $288 \mathrm{bp}$ ). Temperature conditions for
TGF- $\beta R I$ were: hot start at $95^{\circ} \mathrm{C}$ for $5 \mathrm{~min}, 30$ cycles composed of steps at $95^{\circ} \mathrm{C}$ for $1 \mathrm{~min}, 58^{\circ} \mathrm{C}$ for $1 \mathrm{~min}, 72^{\circ} \mathrm{C}$ for $1 \mathrm{~min}$ and a final elongation step at $72^{\circ} \mathrm{C}$ for $7 \mathrm{~min}$.

Primers used for TGF- $\beta$ RII were as follows: $5^{\prime}$-TGTGTTCCTGTAGCTCTGATG-3', and 5'-AGATCTTGACTGCCACTGTCTC-3' (amplified fragment of $432 \mathrm{bp}$ ). Temperature conditions for TGF- $\beta$ RII were: hot start at $94^{\circ} \mathrm{C}$ for $3 \mathrm{~min}, 30$ cycles composed of steps at $94^{\circ} \mathrm{C}$ for $1 \mathrm{~min}, 60^{\circ} \mathrm{C}$ for $1 \mathrm{~min}, 72^{\circ} \mathrm{C}$ for $1 \mathrm{~min}$ and a final elongation step at $72^{\circ} \mathrm{C}$ for $7 \mathrm{~min}$. Primers used for TGF- $\beta$ RIII were as follows: $5^{\prime}$-TGTCACCTGGCACATTCATT3', and 5'-TCTCAGCACTGTCTTGGTGG-3' (amplified fragment of $246 \mathrm{bp}$ ). Temperature conditions for TGF- $\beta$ RIII were: hot start at $94^{\circ} \mathrm{C}$ for $3 \mathrm{~min}, 30$ cycles composed of steps at $94^{\circ} \mathrm{C}$ for $1 \mathrm{~min}, 57^{\circ} \mathrm{C}$ for $1 \mathrm{~min}, 72^{\circ} \mathrm{C}$ for $1 \mathrm{~min}$ and a final elongation step at $72^{\circ} \mathrm{C}$ for $7 \mathrm{~min}$.

Before amplification with each specific primer pairs, an aliquot of the cDNA preparation was amplified using GAPDH primers to determine the efficacy of the generated cDNA. Moreover, we used five different cDNA concentrations to assure that signals (both of GAPDH and of the analysed genes) were proportional to input mRNA. These controls are important for comparison between samples because they ensure that equivalent amounts of RNA are amplified. Finally, each experiment was performed at least in duplicate and, in several cases, in triplicate.

Aliquots of PCR reactions were separated and analysed by electrophoresis on $2 \%(\mathrm{w} / \mathrm{v})$ agarose gels or non-denaturing $8 \%(\mathrm{w} / \mathrm{v})$ polyacrylamide gels (acrylamide/bisacrylamide, 29/1). In the latter case, the amplified products were stained using silver nitrate method. In several cases, the amplified products were recovered from the gels and sequenced as reported in Iolascon et al (1998b). In all cases the sequence of the amplified products corresponded to that reported in the literature.

\section{Immunohistochemistry}

In order to evaluate the TGF- $\beta$ RIII protein level, an immunohistochemical study was carried out on the ten available specimes of neuroblastoma cases already analysed by RT-PCR. The analyses were performed on histological slides from formalin-fixed and paraffin-embedded tumour tissues by using goat polyclonal antibodies raised against the carboxyl terminus of human TGF- $\beta$ RIII (Santa Cruz, sc-6189). Deparaffinized sections underwent a microwave exposition, in $10 \mathrm{mM}$ citrate buffer, $\mathrm{pH} 6$, to retrieve antigenicity and thereafter were treated with $3 \%$ hydrogen peroxide for endogenous peroxidase inactivation. After incubation for $30 \mathrm{~min}$ at room temperature with 1:1000 dilution of primary antibody, the reaction was underscored using a 1:500 diluted rabbit anti-goat antibody at room temperature for $30 \mathrm{~min}$. The immunocomplexes were visualized by using the Envision system (Dako) following manufacturer's instructions. Colourimetric reaction was accomplished using diamminobenzidine as a chromogen.

\section{RESULTS}

Table 1 reports the stage classification and some genetic features of the neuroblastomas analysed. A total of 61 different specimens were studied, classified into five stages (1-4 and $4 \mathrm{~S})$ on the basis of well established clinical criteria. In particular, our investigation involved nine tumours of stage 1 , ten of stage 2 , nine of stage 3,28 of stage 4 and five of stage $4 \mathrm{~S}$. A large percentage of the specimens 
Table 1 Expression of TGF- $\beta 1$ and TGF- $\beta$ receptor type I, II and III genes in human neuroblastoma of different stages

\begin{tabular}{|c|c|c|c|c|c|c|c|}
\hline Sample no. & TGF- $\beta$ RI & TGF- $\beta$ RII & TGF- $\beta$ RIII & TGF- $\beta 1$ & GAPDH & $\mathrm{N}-m y c$ & $1 p$ status \\
\hline \multicolumn{8}{|l|}{ Stage 4S } \\
\hline 586 & + & + & ++ & + & + & 1 & Undel. \\
\hline 809 & +++ & +++ & ++ & + & + & 1 & Tripl./undel. \\
\hline 912 & +++ & ++ & ++ & - & + & 1 & Undel. \\
\hline 803 & +++ & +++ & ++ & ++ & + & 1 & Tripl./undel. \\
\hline 887 & +++ & +++ & + & + & + & 1 & - \\
\hline \multicolumn{8}{|l|}{ Stage 1} \\
\hline 655 & - & + & +++ & ND & + & 1 & Undel. \\
\hline 591 & +++ & ++ & ++ & + & + & 1 & Undel. \\
\hline 823 & +++ & +++ & + & + & + & 1 & Undel. \\
\hline 776 & +++ & - & ++ & - & + & 1 & Undel. \\
\hline 772 & - & + & + & + & + & 1 & Dipl./del. \\
\hline 806 & +++ & - & ++ & - & + & 1 & Tripl./del. \\
\hline 859 & - & - & ++ & + & + & 1 & Tripl./undel. \\
\hline 916 & + & + & ++ & ++ & + & 1 & - \\
\hline 778 & +++ & ++ & - & + & + & 1 & Del. \\
\hline \multicolumn{8}{|l|}{ Stage 2} \\
\hline 606 & +++ & + & + & + & + & 1 & Undel. \\
\hline 652 & +++ & ++ & + & + & + & 1 & Undel. \\
\hline 647 & +++ & ++ & + & + & + & 1 & Undel. \\
\hline 634 & +++ & +++ & + & + & + & 1 & Undel. \\
\hline 852 & +++ & + & + & - & + & 1 & Undel. \\
\hline 851 & +++ & ++ & ++ & - & + & 1 & Undel. \\
\hline 762 & + & - & - & - & + & 1 & Tripl./undel. \\
\hline 764 & +++ & + & - & - & + & 1 & Undel. \\
\hline 656 & + & ++ & - & - & + & 1 & Undel. \\
\hline 626 & +++ & +++ & ++ & + & + & 1 & Undel. \\
\hline \multicolumn{8}{|l|}{ Stage 3} \\
\hline 619 & +++ & + & - & + & + & 13 & Del. 1p32-36 \\
\hline 579 & +++ & + & - & - & + & 1 & Undel. \\
\hline 592 & +++ & - & - & - & + & 12 & Del. 1p32-36 \\
\hline 572 & + & ++ & - & + & + & 1 & Del 1p32 \\
\hline 858 & + & + & - & + & + & 1 & Tripl./undel. \\
\hline 802 & +++ & + & - & & + & 60 & Dipl./undel. \\
\hline 799 & +++ & + & ++ & +++ & 1 & Undel. & \\
\hline 793 & +++ & ++ & - & + & + & 1 & Undel. \\
\hline 698 & + & +++ & ++ & + & + & 1 & - \\
\hline \multicolumn{8}{|l|}{ Stage 4} \\
\hline 687 & - & - & - & + & + & 20 & Undel. \\
\hline 640 & +++ & ++ & - & + & + & 1 & Undel. \\
\hline 691 & + & +++ & - & ++ & + & 1 & Undel. \\
\hline 651 & - & - & - & + & + & 7 & Del. 1p32-36 \\
\hline 945 & ND & +++ & ++ & ND & + & Ampl. & Undel. \\
\hline 718 & +++ & +++ & + & + & + & 1 & - \\
\hline 811 & +++ & +++ & + & + & + & 1 & Undel. \\
\hline 870 & + & - & - & + & + & 1 & - \\
\hline 871 & +++ & +++ & - & + & + & 1 & Undel. \\
\hline 872 & +++ & +++ & + & +++ & + & 1 & Tetr./undel. \\
\hline 876 & +++ & +++ & + & + & + & 1 & Undel. \\
\hline 882 & ++ & +++ & ++ & +++ & + & 1 & Tripl./undel. \\
\hline 701 & +++ & +++ & ++ & + & + & 1 & - \\
\hline 846 & +++ & ++ & - & - & + & 1 & Undel. \\
\hline 728 & ND & + & + & ND & + & 1 & Undel. \\
\hline 780 & + & ++ & - & + & + & 1 & Undel. \\
\hline 837 & +++ & ++ & - & + & + & 1 & Undel. \\
\hline 834 & +++ & ++ & - & + & + & 1 & Del. \\
\hline 321 & +++ & +++ & - & + & + & Ampl. & Del. \\
\hline 292 & ++ & ++ & - & +++ & + & Ampl. & Del. \\
\hline 505 & +++ & +++ & - & + & + & Ampl. & Del. \\
\hline 350 & +++ & ++ & - & + & + & Ampl. & - \\
\hline 690 & +++ & +++ & - & + & + & Ampl. & Del. \\
\hline 664 & +++ & ++ & - & + & + & Ampl. & Del. \\
\hline 597 & + & ++ & - & + & + & Ampl. & - \\
\hline 753 & +++ & ++ & - & + & + & Ampl. & - \\
\hline 651 & +++ & ++ & - & +++ & + & Ampl. & - \\
\hline 644 & +++ & ++ & - & + & + & Ampl. & - \\
\hline
\end{tabular}

$\mathrm{N}$-myc reports the number of copies of the gene or if the gene is amplified. The symbols,,-+++ and +++ represent the relative amount of the PCR product estimated by laser scanner analysis. These results were generally a mean of three different experiments. Del., deleted; Ampl., amplified; Tetr., ternary; Tripl., triplicate; Undel., undeleted. 


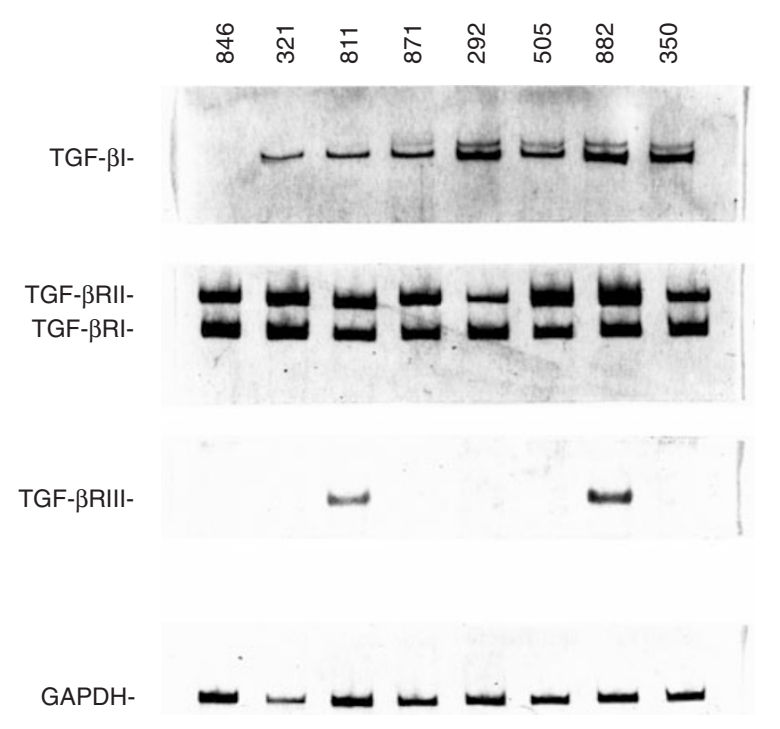

Figure 1 Analysis of TGF- $\beta 1$, TGF- $\beta$ RI, TGF- $\beta$ RII and TGF- $\beta$ RII mRNA in human neuroblastoma specimens. Total RNA $(2.5 \mu \mathrm{g})$ was reverse transcribed as described under Materials and Methods. cDNA samples were then diluted in a PCR assay and amplified by specific primers. Aliquots of PCR reaction $(5 \mu \mathrm{l})$ were separated by non-denaturing $8 \%$ polyacrylamide ge and stained by silver nitrate method. Finally, the relative amount of each amplified product was determined by densitometric scanner. From the top to the bottom: TGF- $\beta 1$ gene, TGF- $\beta$ RII gene TGF- $\beta$ RI, TGF- $\beta$ RIII gene and GAPDH gene. Numbers reported at the top of panels represent samples examined

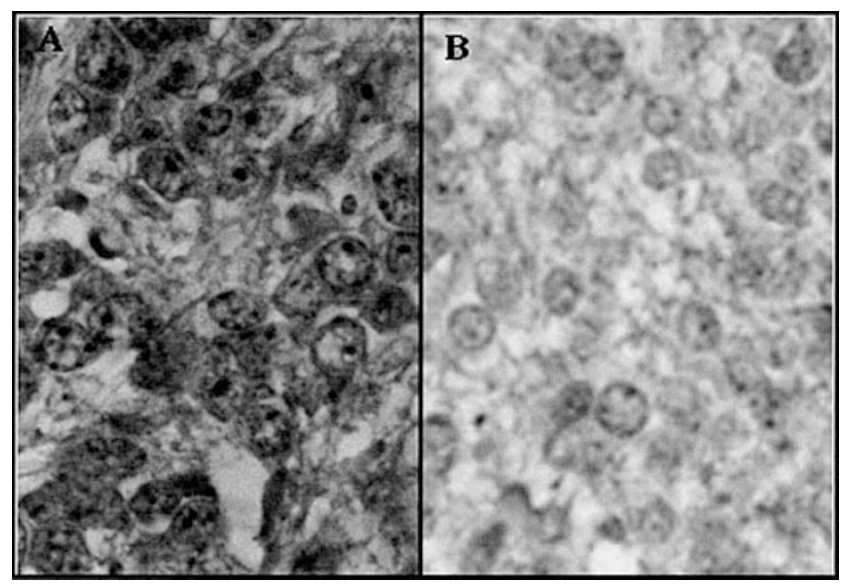

Figure 2 Immunochemical analysis of TGF- $\beta$ RIII protein in human neuroblastoma samples. Specimens of neuroblastomas showing high level of TGF- $\beta$ RIII protein (A, sample no. 912) or the absence of the receptor (B, sample no. 651). Details on the immunochemical staining technique are reported in Materials and Methods

were previously investigated for $\mathrm{N}-m y c$ gene amplification and genetic alteration at $1 \mathrm{p}$ level (Iolascon et al, 1998c). Each cancer sample was analysed for the expression of TGF- $\beta 1$, TGF- $\beta$ RI, TGF- $\beta$ RII and TGF- $\beta$ RIII genes by means of RT-PCR methodology. Ten specimens were also studied by immunohistochemistry for TGF- $\beta$ RIII protein.
Table 2 mRNA and protein TGF- $\beta$ RIII level in human neuroblastoma of different stages

\begin{tabular}{|c|c|c|}
\hline Sample no. & $\begin{array}{l}\text { TGF- } \beta R I I I \\
\text { mRNA }^{a}\end{array}$ & $\begin{array}{l}\text { TGF- } \beta \text { RIII protein } \\
\text { (\% of positive cells) }^{\mathrm{b}}\end{array}$ \\
\hline \multicolumn{3}{|l|}{ Stage 4S } \\
\hline 809 & ++ & $>75$ \\
\hline 912 & ++ & $>75$ \\
\hline \multicolumn{3}{|l|}{ Stage 1} \\
\hline 806 & ++ & $>75$ \\
\hline 859 & ++ & $>75$ \\
\hline 778 & - & $<20$ \\
\hline $\begin{array}{c}\text { Stage } 2 \\
764\end{array}$ & - & Absent \\
\hline $\begin{array}{c}\text { Stage } 3 \\
802\end{array}$ & - & Absent \\
\hline \multicolumn{3}{|l|}{ Stage 4} \\
\hline 651 & - & Absent \\
\hline 690 & - & $<10$ \\
\hline 882 & ++ & $>70$ \\
\hline
\end{tabular}

aDetermined by RT-PCR. 'Determined by immunochemical methodologies

\section{Expression of TGF- $\beta 1$ gene and of TGF- $\beta$ RI, -RII and -RIII genes}

Figure 1 shows examples of TGF- $\beta 1$, TGF- $\beta$ RI, TGF- $\beta$ RII and TGF- $\beta$ RIII gene expression analysed by means of RT-PCR in some neuroblastoma specimens.

TGF- $\beta 1$ mRNA occurred in neuroblastomas of all stages with small variations (from $60 \%$ to $90 \%$ of samples from different stages) (Table 1). The gene encoding TGF- $\beta$ RI and TGF- $\beta$ RII was expressed in all neuroblastomas of stage $4 \mathrm{~S}$ and in the majority of specimens belonging to the other stages, including particularly those of stage 4 (Table 1).

The analysis of the transcription of TGF- $\beta$ RIII gene in stage $4 \mathrm{~S}$ cancers showed that all specimens $(100 \%)$ presented the expression of the gene (Table 1). When we investigated TGF- $\beta$ RIII mRNA in the other neuroblastoma samples we observed an enormous decrease from stage $1(89 \%)$ and stage $2(70 \%)$ to stage 3 $(23 \%)$ and stage $4(29 \%)$. Importantly, almost all (12 out of 13 , $92 \%$ ) stage 4 and all (three out of three, 100\%) stage 3 cancers with $\mathrm{N}-m y c$-amplified gene did not express TGF- $\beta$ RIII gene.

\section{Immunohistochemistochemical analyses}

Table 2 reports the results of the immunohistochemical investigation carried out on ten specimens of neuroblastoma. We analysed two samples of neuroblastomas of stage $4 \mathrm{~S}$, three of stage 1 , one of stages 2 and 3 respectively, and three specimens of stage 4 . In the last case, we studied one sample containing high levels of TGF$\beta R I I I$ gene mRNA and two specimens that do not contain this mRNA. The data obtained, which were reported as percentage of positive cells, strongly confirm, at protein level, the results of RTPCR studies. Figure 2 shows examples of two neuroblastoma samples analysed by specific TGF- $\beta$ RIII antibodies. It is evident from the images the occurrence of strong signals, in the positive cells, at cellular membrane level. 


\section{DISCUSSION}

Cell growth and differentiation are two fundamental aspects of multicellular existence and, intertwined with these processes, is the phenomenon of unlimited growth, which is the basis of the neoplastic state. Indeed, cancer might be envisaged as the result of unregulated proliferation of a given cell, frequently due to a block of its ability to undergo differentiation. The present paper reports the results of a study aimed to investigate the expression, in human neuroblastomas, of genes involved in the regulation of TGF- $\beta$ pathway which plays a key role in the control of the molecular interplay between proliferation and differentiation. All the analysed samples contained more than $95 \%$ malignant cells, thus our findings were not (or scarcely) influenced by the occurrence of normal cells in the specimens.

Although TGF- $\beta$ is one of the most potent inhibitors of cell growth, several malignancies of different origin are resistant to TGF- $\beta$, suggesting that the developing of unresponsiveness to this molecule plays an important role in cancerogenesis (Polyak, 1966). Tumours acquire resistance to TGF- $\beta$ relatively late during malignant progression and this appears to be associated with developing invasiveness (Filmus and Kerbel, 1993; Fynan and Reiss, 1993). Although the loss of TGF- $\beta$ RII has been reported in retinoblastomas and certain colon carcinoma cell lines (Coffey et al, 1987; Kimchi et al, 1988), it occurs quite infrequently. Conversely, decreased expression of TGF- $\beta$ RII has been frequently observed in human tumours and cell lines (Filmus et al, 1992; Kadin et al, 1994; Matoba et al, 1998; Royuela et al, 1998; Hougaard at al, 1999), and this phenomenon may result in resistance to TGF- $\beta$ growth inhibitory activity. When we analysed the TGF- $\beta$ RII gene expression in human neuroblastomas, we observed that all the neoplasias of stage $4 \mathrm{~S}$ and the large majority of neuroblastomas of the other stages expressed this specific transcript (Table 1). Thus, these results argue against down-regulation of TGF-BRII expression as an important factor in neuroblastoma development and/or progression. Moreover, no remarkable variation in the expression of TGF- $\beta$ RI (and of TGF- $\beta 1$ ) gene was observable in tumours of different stages.

Very recently it has been demonstrated that TGF- $\beta$ RIII is also critical in the response to various TGF- $\beta$ isoforms, and that its overexpression might restore the growth inhibitory effect of TGF$\beta$ in the presence of low level TGF- $\beta$ RII (Chen et al, 1997). Thus, the membrane content of TGF- $\beta$ RIII is important in TGF- $\beta$ growth control.

Our results show that TGF- $\beta$ RIII gene expression is significantly reduced in neuroblastomas of stage 3 and 4 . Conversely, all cancers of stage $4 \mathrm{~S}$ (which spontaneoulsy undergo differentiation) and most stage 1 and 2 tumours express remarkable levels of the TGF- $\beta$ RIII mRNA. These findings were obtained by employing a quantitative RT-PCR technique and confirmed (on the available samples) by direct immunohistochemical analysis. Thus, the data reported in the present paper demonstrate, for the first time, that neuroblastomas with a worst prognosis and high invasiveness show down-regulation of TGF- $\beta$ RIII gene transcription. Although the molecular mechanism responsible for this phenomenon is not known and is currently under investigation, it is totally conceivable that the absence of TGF- $\beta$ RIII might result in an escape of TGF- $\beta$ antiproliferative action.

TGF- $\beta$ RIII (also known as $\beta$-glycan) gene belongs to a growth factor receptor category which is not coupled to cytoplasmatic structures involved in signalling pathways. This family also includes the p75 gene (encoding a low affinity receptor for nerve growth factor and neurotrophins) (Johnson et al, 1986; Radeke et al, 1987), syndecan and other proteoglycans (whose heparin sulphate chains bind fibroblast growth factors) (Saunders et al, 1989; Kiefer et al, 1990) and the type II receptor for insulin-like growth factors (Morgan et al, 1987; MacDonald et al, 1988). These molecules are of lower affinity and are generally more abundant than the corresponding signalling receptors, properties that might allow them to act as enhancers of growth factor access to the receptors (Lòpez-Casillas et al, 1993). $\beta$-glycan is a membrane proteoglycan with heparin and chondrotin sulphate chains attached to a $100 \mathrm{kDa}$ core protein (Lòpez-Casillas et al, 1991; Wang et al, 1991). This protein forms a ternary complex with a TGF- $\beta$ molecule and the TGF- $\beta$ RII (Lòpez-Casillas et al, 1993) and increases receptor binding affinity and cell responsiveness to TGF- $\beta$ (Lòpez-Casillas et al, 1993). For example, in the absence of $\beta$ glycan, TGF- $\beta$ RII binds TGF- $\beta 1$ with a low affinity $\left(K_{\mathrm{D}}\right.$ of $\left.0.5 \mathrm{nM}\right)$ and no detectable affinity for TGF- $\beta 2$ (Lòpez-Casillas et al, 1993). Conversely, the complex TGF- $\beta$ RII-TGF- $\beta$ RIII has an affinity for TGF- $\beta$ (both type 1 and type 2 ) in the physiological range (50 pM and lower). Subsequently, the TGF- $\beta$ RII-TGF- $\beta$ dimer leaves TGF- $\beta$ RIII and associates with TGF- $\beta$ RI forming a ternary complex which activates the signalling pathway. This mechanism establishes that $\beta$-glycan membrane level is a direct modulator of TGF- $\beta$ access to the signalling receptor.

It is well established that retinoic acid induces neuroblastoma cell line differentiation. Moreover, clinical trials are under development in order to evaluate the therapeutical utility in neuroblastoma treatment of retinoic acid and its analogues. It has previously been demonstrated that retinoic-dependent neuroblastoma cell line differentiation is strictly associated with TGF- $\beta$ secretion and upregulation of all the TGF- $\beta$ receptor forms (Cohen et al, 1995). This finding supports the view that the presence of an efficacious TGF- $\beta$ response is important in neuroblastoma differentiation and that its loss might play a role in the establishment of high-stage neoplasias. Accordingly it is interesting that stage $4 \mathrm{~S}$ neuroblastomas, which spontaneously evolve towards a differentiated phenotype, express all TGF- $\beta$ receptor genes (Table 1$)$. It is also intriguing that almost all neuroblastomas (14 out of 15 samples, $94 \%$ ) with N-myc gene amplification (a well established marker of worst evolution) show absence of TGF- $\beta$ RIII gene expression (Table 1). This result suggests a possible correlation between $\mathrm{N}$ $m y c$ overexpression and reduced TGF- $\beta$ response also in view of the observation that retinoic acid treatment of neuroblastoma cell lines causes a down-regulation of $\mathrm{N}-m y c$ expression and induction of TGF- $\beta$ receptor expression (Cohen et al, 1995). Future studies will be devoted to investigating the existence of this interesting relationship.

In conclusion, our studies suggest the possible occurrence of an impairment of TGF- $\beta$ response in neuroblastomas of stage 3 and 4 , due to specific down-regulation of TGF- $\beta$ RIII gene expression. It is to be stressed that the present study confirms and remarkably extends the only previous observation showing the absence of TGF-ßRIII in human tumours (Bristow et al, 1999), thus leading to the proposal of a completely novel mechanism for escaping TGF$\beta$ growth inhibitory activity in malignancies.

Due to the increasing relevance of TGF- $\beta$-dependent pathway aberrations in human tumorigenesis, further studies are required to evaluate the level and activity of other components, particularly DPC4 (SMAD4) and SMAD2 (White, 1998), in human neuroblastomas. 


\section{ACKNOWLEDGEMENTS}

This work is supported by Fondazione Italiana per la Ricerca sul Cancro (FIRC), by Associazione Italiana per la Ricerca sul Cancro (AIRC), by MURST and by Associazione Italiana per la Lotta al Neuroblastoma.

\section{REFERENCES}

Bristow RE, Baldwin RL, Yamada SD, Kore M and Karlan BY (1999) Altered expression of transforming growth factor-beta ligands and receptors in primary and recurrent ovarian carcinoma. Cancer 85: 658-668

Brodeur GM, Pritchard J, Berthold F, Carlsen NL, Castel V, Castelberry RP, De Bernardi B, Evans AE, Favrot M and Hedborg F (1993) Revisions of the international criteria for neuroblastoma diagnosis, staging and response to treatment. J Clin Oncol 8: 1466-1477

Chen C, Wang X-F and Sun LZ (1997) Expression of transforming growth factor $\beta$ (TGF $\beta$ ) type III restores autocrine TGF $\beta 1$ activity in human breast cancer MCF-7 cells. J Biol Chem 272: 12862-12867

Coffey RL, Kost LJ, Lyons RM, Moses HL and LaRusso NF (1987) Hepatic processing of transforming factor $\beta$ in the rat. $J$ Clin Invest 80: 750-757

Cohen PS, Letterio JJ, Gaetano C, Chan J, Matsumoto K, Sporn MB and Thiele CJ (1995) Induction of transforming growth factor beta 1 and its receptors during all-trans-retinoic acid (RA) treatment of RA-responsive human neuroblastoma cell lines. Cancer Res 55: 2380-2386

Filmus J and Kerbel RS (1993) Development of resistance mechanisms to the growth-inhibitory effects of transforming growth factor- $\beta$ during tumor progression. Curr Opin Oncol 5: 123-129

Filmus J, Zhao J and Buick RN (1992) Overexpression of H-ras oncogene induces resistance to the growth inhibitory action of the transforming growth factor beta-1 (TGF- $\beta 1$ ) and alters the number of TGF- $\beta 1$ receptors in rat intestinal epithelial cell clones. Oncogene 7: 521-526

Fynan TM and Reiss M (1993) Resistance to inhibition of cell growth by transforming growth factor- $\beta$ and its role in oncogenesis. Crit Rev Onc 4: 493-540

Heldin CH, Miyazono K and Dijke P (1997) TGF- $\beta$ signaling from cell membrane to nucleus through SMAD proteins. Nature 390: $465-471$

Hougaard S, Norgaard P, Abrahamsen N, Moses HL, Spang-Thomsen M and Skovgaard Poulsen H (1999) Inactivation of the transforming growth factor beta type II receptor in human cell lung cancer cell lines. Br J Cancer 79: 10065-1011

Iolascon A, Giordani L, Moretti A, Tonini GP, Lo Cunsolo C, Mastropietro S, Borriello A and Della Ragione F (1998a) Structural and functional analysis of cyclin dependent kinase inhibitor genes (CDKN2A, CDKN2B and CDKN2C) in neuroblastoma. Pediatr Res 43: 139-144

Iolascon A, Giordani L, Moretti A, Basso G, Borriello A and Della Ragione F (1998b) Analysis of CDKN2A, CDKN2B, CDKN2C and cyclin D genes status in hepatoblastoma. Hepatology 27: 989-995

Iolascon A, Lo Cunsolo C, Giordani L, Cusano R, Mazzocco K, Boumgartner M, Ghisellini P, Faienza MF, Boni L, De Bernardi B, Conte M, Romeo G and Tonini GP (1998c) Interstizial and large 1p deletion occurs in localized and disseminated neuroblastomas and predict an unfavorable outcome. Cancer Lett 130: $83-92$

Johnson D, Lanahan A, Buck CR, Sehagal A, Morgan C, Mercer E, Bothwell M and Chao M (1986) Expression and structure of the human NGF receptor. Cell 47: $545-554$

Kadin ME, Cavaille-Coll MW, Gertz R, Massagué J, Cheifetz S and George D (1994) Loss of receptors for transforming growth factor $\beta$ in human T-cell malignancies. Proc Natl Acad Sci USA 91: 6002-6006
Kiefer MC, Stephans JC, Crawford K, Okino K and Barr PJ (1990) Ligand-affinity cloning and structure of a cell surface heparin sulfate proteoglycan that binds basic fibroblast growth factor. Proc Natl Acad Sci USA 87: 6985-6989

Kimchi A, Wang X-F, Weinberg RA, Cheifetz S and Massague J (1988) Absence of TGF- $\beta$ receptors and growth inhibitory responses in retinoblastoma cells. Science 240: 196-199

Lòpez-Casillas F, Cheifetz S, Doody J, Andres JL, Lane WS and Massagué J (1991) Structure and expression of the membrane proteoglycan betaglycan, a component of the TGF- $\beta$ receptor system. Cell 67: 785-795

Lòpez-Casillas F, Wrana JL and Massagué J (1993) Betaglycan presents ligand to the TGF $\beta$ signaling receptor. Cell 73: $1435-1444$

Lu S-L, Akiyama Y, Saitoh K and Yuasia Y (1995) Mutations of the transforming growth factor- $\beta$ type II receptor gene and genomic instability in hereditary nonpolyposis colorectal cancer. Biochem Biophys Res Commun 216: $452-457$

MacDonald RG, Pleffer SR, Coussens L, Tepper MA, Brocklebank CM, Mole JE, Anderson JK, Chen E, Czech MP and Ullrich A (1988) A single receptor binds both insulin-like growth factor II and mannose-6-phosphate. Science 239: 1134-1137

Maniatis T, Fritsh E, Sambrook J (1990) Molecular cloning. In: Cold Spring Harbor Laboratory, A Laboratory Manual, pp. 7.6-7.22, 9.16-9.23. Cold Spring Harbor: New York

Markowitz S, Wang J, Myeroff L, Parson R, Sun L-Z, Lutterbugh J, Fan RS, Zborowska E, Vogelstein B, Brattain M and Wilson JKV (1995) Inactivation of the type II TGF- $\beta$ receptor in colon cancer cells with microsatellite instability. Science 268: 1336-1338

Matoba H, Sagano S, Yamaguchi N and Miyachi Y (1998) Expression of transforming growth factor-beta 1 and transforming growth factor-beta type-II receptor mRNA in papillary thyroid carcinoma. Hormone Metab Res 30: 624-628

Morgan DD, Edman JC, Standring DN, Fried VA, Smith MC, Roth RA and Rutter WJ (1987) Insulin-like growth factor II receptor as a multifunctional binding protein. Nature 329: 301-307

Pinkerton CR (1993) A clinical perspective in human neuroblastoma: recent advances in clinical and genetics analysis. In: Neuroblastoma in the 1990s, Schwab M, Tonin GP and Benard J (eds), pp. 3-10. Harwood Academic: Chur. Switzerland

Polyak K (1996) Negative regulation of cell growth by TGFß. Biochim Biophys Acta 1242: $185-199$

Radeke MJ, Misko TP, Hsu C, Herzenberg LA and Shooter EM (1987) Gene transfer and molecular cloning of the rat nerve growth factor receptor. Nature $\mathbf{3 2 5}$ : 593-597

Royuela M, De Miguel MP, Bethencourt FR, Sanchez-Chapado M, Fraile N and Paniagua R (1998) Transforming growth factor beta 1 and its receptor types I and II. Comparison in human prostate, benign prostatic hyperplasia and prostatic carcinoma. Growth Factors 16: 101-110

Saunders S, Jalkanen M, O'Farrell S and Bernfield M (1989) Molecular cloning of syndecan, an integral membrane proteoglycan. J Cell Biol 108: 1547-1556

Siegel SE and Sato JK (1986) Neuroblastoma. In: Oncology, Moossa AR, Robson MC and Schimpfl SC (eds), pp. 1211-1231. Williams and Wilkins: Baltimore

Sun LZ, Wu G, Willson JKV, Zborowska E, Yang J, Rajkarunanayake I, Wang J, Gentry LE, Wang XF and Brattain MG (1994) Expression of transforming growth factor $\beta$ type II receptor leads to reduced malignancy in human breast cancer MCF-7 cells. J Biol Chem 269: 26449-26455

Wang X-F, Lin HY, Ng-Eaton E, Downward J, Ldish HF and Weinberg RA (1991) Expression cloning and characterization of the TGF- $\beta$ type III receptor. Cell 37: 797-805

Wang J, Han W, Zbrowska E, Liang J, Wang X, Willson JKV, Sun LZ and Brattain MG (1996) Reduced expression of transforming growth factor b type I receptor contributes to the malignancy of human colon carcinoma cells. J Biol Chem 271: $17366-17371$

White RL (1998) Tumor suppressor pathways. Cell 92: 591-592 